\title{
FIRST REPORT OF TEARDROP THREADFIN BREAM, NEMIPTERUS ISACANTHUS (ACTINOPTERYGII: PERCIFORMES: NEMIPTERIDAE), FROM THE SOLOMON SEA, PAPUA NEW GUINEA
}

\author{
Ken LONGENECKER ${ }^{1 *}$ and Ham GIAMSA ${ }^{2}$ \\ ${ }^{1}$ Department of Natural Sciences, Bishop Museum, Honolulu, Hawaii, USA \\ ${ }^{2}$ Kamiali Wildlife Management Area, Lababia, Morobe Province, Papua New Guinea
}

Longenecker K., Giamsa H. 2016. First report of teardrop threadfin bream, Nemipterus isacanthus (Actinopterygii: Perciformes: Nemipteridae), from the Solomon Sea, Papua New Guinea. Acta Ichthyol. Piscat. 46 (2): 119-121.

\begin{abstract}
The teardrop threadfin bream, Nemipterus isacanthus (Bleeker, 1873), is reported from northern New Guinea for the first time based on specimens caught by hook and line, and photographed in June 2008 and September 2014 at Kamiali Wildlife Management Area (KWMA), Morobe Province, Papua New Guinea. A large, permanent population exists at KWMA, thus the known range of $N$. isacanthus is extended by at least $1400 \mathrm{~km}$. Morphometric and meristic data for specimens caught in September 2014 are provided.
\end{abstract}

Keywords: Lababia, Morobe Province, new record, range extension

Nine Nemipterus species have been reported, in monitoring curriculum (Longenecker et al. 2012). The checklists and aids to identification, from the island of senior author encountered the species again at KWMA on New Guinea: Nemipterus balinensis (Bleeker, 1858) 11 September 2014 when photographing another catch by by Fricke et al. 2014; Nemipterus celebicus (Bleeker, the junior author.

1854), Nemipterus hexodon (Quoy et Gaimard, 1824), Nemipterus peronii (Valenciennes, 1830) by Munro 1958; Nemipterus aurifilum (Ogilby, 1910) by Kailola 1987; Nemipterus bathybius Snyder, 1911, Nemipterus furcosus (Valenciennes, 1830), Nemipterus marginatus (Valenciennes, 1830), and Nemipterus nematopus (Bleeker, 1851) by Russell 1990. Only three of these, N. balinensis, $N$. hexodon, and $N$. peronii, have known distributions that include the northern coast of mainland Papua New Guinea on which Kamiali Wildlife Management Area (KWMA) is situated $\left(7^{\circ} 18^{\prime} \mathrm{S}, 147^{\circ} 10^{\prime} \mathrm{E}\right)$.

Alongi et al. (1992) reported catching three Nemipterus isacanthus (Bleeker, 1873) specimens in the Gulf of Papua (approximately $9^{\circ} 1^{\prime} \mathrm{S}, 143^{\circ} 53^{\prime} \mathrm{E}$ ), off the southern coast of New Guinea. However, the specimens may have been waifs; there appears to be no other reports of the species from New Guinea waters, and the island was not included within the range of $N$. isacanthus in a later treatment of nemipterids (Russell 1990).

Several lines of evidence suggest that a large and permanent population of Nemipterus isacanthus exists at KWMA. First, the species is common enough to have a local name. It is called imili in Kala (the vernacular language at KWMA and five nearby villages). Second, KWMA residents can describe the habitat where $N$. isacanthus is most likely to be caught (over sand near the edge of coral reefs, at depths between 30 and $90 \mathrm{~m}$ ). Third, fishermen at KMWA suggested it would make a good candidate for rapid reproductive analysis (see Longenecker et al. 2014) because they could easily catch the required 125 specimens within the four-month period allotted for collection. In fact, they caught 98 specimens during 12 days of fishing in February 2015. Fourth, it appears to form a large part of the subsistence fish catch at KWMA. N. isacanthus represents $23 \%$ of individuals in the senior author's photographs of the junior author's two catches.

The presence of Nemipterus isacanthus at KWMA represents an approximately $1400 \mathrm{~km}$ range extension for the species (Fig. 1). Russell (1990) listed its distribution as the Philippines, Gulf of Thailand, Strait of Malacca, Indonesia, and northern Australia. The distribution map in Russell (1990) indicates that, north of New Guinea, the eastern limit is located between

* Correspondence: Dr. Ken Longenecker, Department of Natural Science, Bishop Museum, 1525 Bernice Street, Honolulu, HI, 96817 , USA, phone: +1 808 847 8273, fax +1 808847 8252, e-mail: (KL) klongenecker@bishopmuseum.org. 
Mindanao (Philippines) and the northeastern tip of Sulawesi (Indonesia), whereas south of New Guinea, the eastern limit is the Gove Peninsula, northern Australia. The distance between these limits and KWMA is approximately 2750 and $2300 \mathrm{~km}$, respectively. The latter distance is the shortest water route between Gove Peninsula and KWMA (i.e., around the eastern tip of New Guinea). We also examined georeferenced occurrence records from the Global Biodiversity Information Facility [GBIF.org (23rd February 2016) GBIF Occurrence Download http:// doi.org/10.15468/dl.shlvzh GBIF]. These records indicate that, north of New Guinea, the collection site nearest KWMA was on the west side of Luzon (Philippines), whereas south of New Guinea, the collection site nearest KWMA was in the Gulf of Carpentaria The distance between these points and KWMA is approximately 3750 and $1900 \mathrm{~km}$, respectively. Again, the latter distance represents the shortest water route. Finally, the shortest water route between KWMA and the site where it was reported by Alongi et al. (1992) in the Gulf of Papua is approximately $1400 \mathrm{~km}$.

Habitat suitable for Nemipterus isacanthus almost certainly exists between KWMA and its previously reported occurrences and distributional limits. The rarity of previous reports from New Guinea may reflect limited collecting effort. It seems reasonable to include New Guinea in the principal range of $N$. isacanthus.

No specimens of Nemipterus isacanthus from New Guinea have been deposited in museum collections. Here we use the terminology of Russell 1990 to describe $N$. isacanthus at KWMA based on meristic counts taken from fresh specimens collected 11 September 2014; and morphological, morphometric, and colour characters

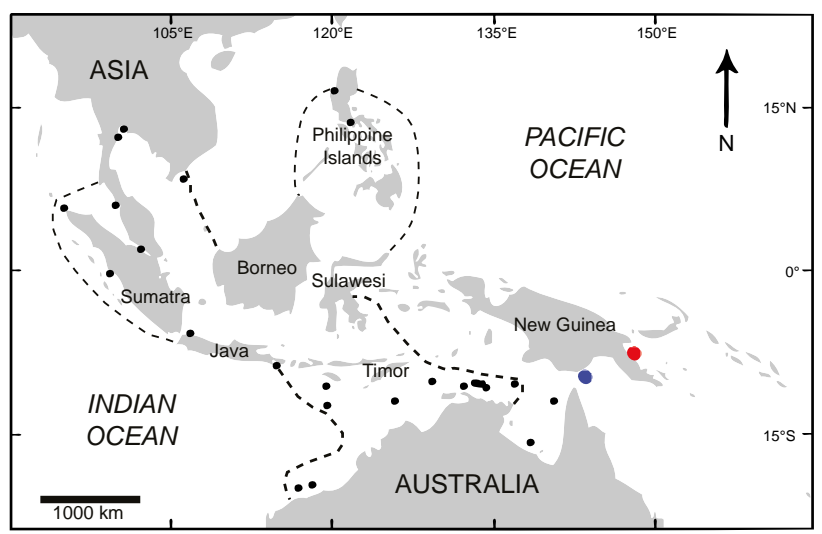

Fig. 1. Occurrence records for Nemipterus isacanthus; Red circle indicates Kamiali Wildlife Management Area, Papua New Guinea. Dashed line indicates the approximate distribution boundaries presented by Russell (1990); Black circles indicate georeferenced records from the Global Biodiversity Information Facility, exclusive of questionable records from Africa [GBIF.org (23rd February 2016) GBIF Occurrence Download http://doi.org/10.15468/dl.shlvzh GBIF]; Blue circle indicates the approximate location of specimens reported by Alongi et al. (1992) obtained by examination of photographs of one of the specimens (Fig. 2). Morphometric measurements were made with image analysis software. Meristic and morphometric data are presented in Table 1. Head: lower margin of eye located above a line drawn from tip of snout to upper base of pectoral fin; a line drawn from posterior edge of suborbital reaching dorsal profile 2 scale rows before origin of dorsal fin. Body: scales below lateral line arranged in near-horizontal rows. Pectoral fins reach beyond anus. Dorsal fin continuous; membrane between spines slightly emarginate; first two spines separated by a membrane, shorter than the following spines, and not produced into a long filament. Anal fin: last ray elongate. Caudal fin: forked; upper lobe falcate, not produced into an elongate point or extended into a narrow filament. Colour: background of head and body pink dorsally, fading to silver-white ventrally; upper lip yellow; yellow bar extending obliquely forward from bottom of eye toward angle of mouth; two pale yellow stripes along body, the superior one from beneath origin of lateral line to upper caudal fin base, the inferior one from behind pectoral fin base to lower caudal fin base; ventral surface yellow from isthmus to caudal fin base; dorsal fin translucent, with narrow yellow margin and submedial stripe; caudal fin pink, tip of upper lobe bright yellow. The maximum and average fork length of 125 specimens collected FebruaryJune 2015 was 24.9 and $15.2 \mathrm{~cm}$, respectively. These characters agree completely with Russell (1990), the aidto-identification used to identify the specimens.

Table 1

Meristic and morphometric data for Nempiterus isacanthus from Kamiali Wildlife Management Area, Papua New Guinea

\begin{tabular}{lc}
\hline \multicolumn{1}{c}{ Character } & Value \\
\hline Dorsal fin & X, 9 \\
Anal fin & III, 7 \\
Pectoral fin & 14 \\
Suborbital depth/eye diameter & 0.94 \\
Snout/eye diameter & 1.15 \\
Head length/eye diameter & 3.31 \\
Standard length/body depth & 3.10 \\
Pectoral fin length/head length & 1.00 \\
\hline
\end{tabular}

\section{ACKNOWLEDGEMENTS}

We thank Barry C. Russell for identifying Nemipterus isacanthus from our photographs. A private foundation, wishing to remain anonymous, provided financial support. This is contribution 2016-001 to the Pacific Biological Survey.

\section{REFERENCES}

Alongi D.M., Christoffersen P., Tirendi F., Robertson A.I. 1992. The influence of freshwater and material export on sedimentary facies and benthic processes within the Fly Delta and adjacent Gulf of Papua (Papua New Guinea). Continental Shelf Research 12 (2-3): 287-326. 


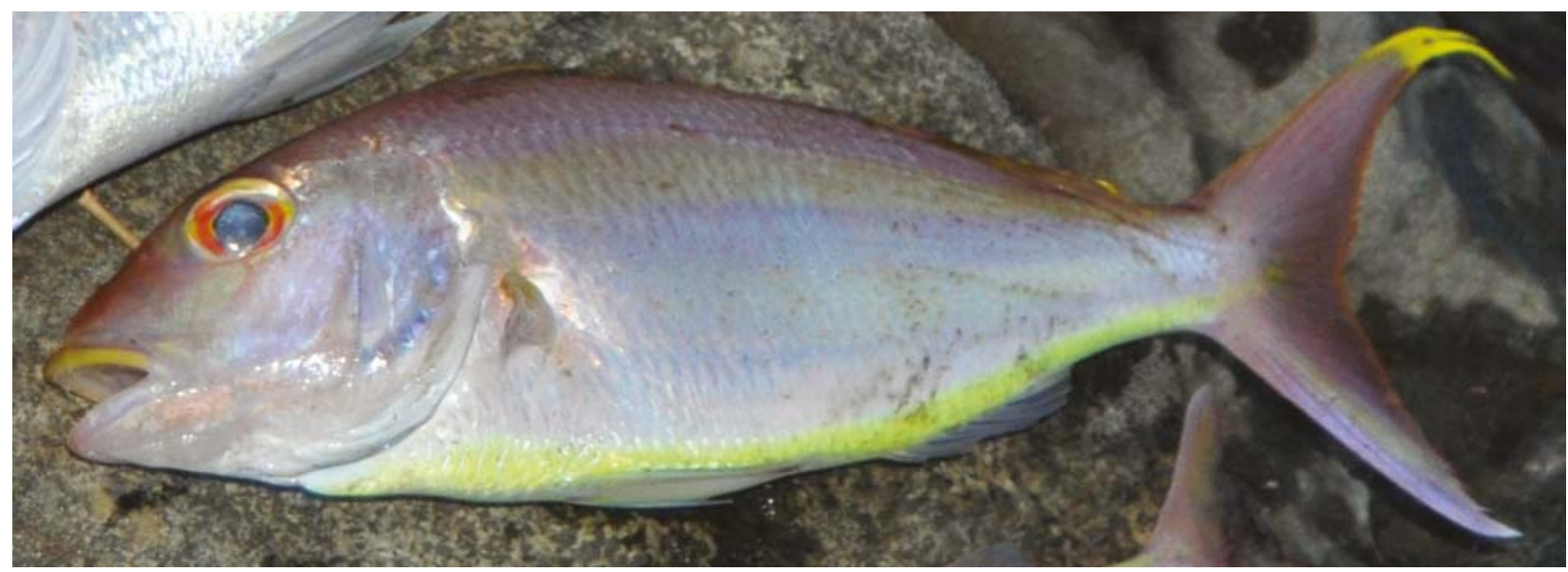

Fig. 2. Nemipterus isacanthus taken by handline from Kamiali Wildlife Management Area, Papua New Guinea on 11 September 2014

Fricke R., Allen G.R., Andréfouët S., Chen W., Hamel M.A., Laboute P., Mana R., Hui T.H., Uyeno D. 2014. Checklist of the marine and estuarine fishes of Madang District, Papua New Guinea, western Pacific Ocean, with 820 new records. Zootaxa 3832 (1): 1-247.

DOI: $10.11646 /$ zootaxa.3832.1.1

Kailola P.J. 1987. The fishes of Papua New Guinea: a revised and annotated checklist. Vol. II Scorpaenidae to Callionymidae. Research Bulletin No. 41, Research Section, Dept. of Fisheries and Marine Resources, Papua New Guinea.

Longenecker K., Abel D., Boruru R., Nandang T., Reuben G., Schreyer C., Wagner J. 2012. Monitoring village fish resources (Lukautim Ples Pis Na Risos Bilong En; Koto Kana I De Ambola Ma Gele Golotome): A school-based fishery project. Pacific Biological Survey Contribution 2012-006.

Longenecker K., Bolick H., Allison A. 2008. A preliminary account of marine fish diversity and exploitation at Kamiali Wildlife Management Area,
Papua New Guinea. Bishop Museum Technical Report No. 46.

Longenecker K., Langston R., Bolick H., Kondio U. 2014. Rapid reproductive analysis and lengthweight relation for red-bellied fusilier, Caesio cuning, and longfin emperor, Lethrinus erythropterus (Actinopterygii: Perciformes: Caesiondiae and Lethrinidae) from a remote village in Papua New Guinea. Acta Ichthyologica et Piscatoria 44 (1): 75-84. DOI: $10.3750 / A I P 2014.44 .1 .10$

Munro I.S.R. 1958. The Fish of the New Guinea Region: a check-list of the fishes of New Guinea incorporating records of species collected by the Fisheries Survey Vessel "Fairwind" during the years 1948 to 1950 . Territory of Papua and New Guinea Fisheries Bulletin 1: 97-369.

Russell B.C. 1990. FAO species catalogue. Vol. 12. Nemipterid fishes of the world (threadfin breams, whiptail breams, monocle breams, dwarf monocle breams, and coral breams). Family Nemipteridae. An annotated and illustrated catalogue of nemipterid species known to date. FAO Fisheries Synopsis.

Received: 29 February 2016 Accepted: 23 May 2016 Published electronically: 30 June 2016 